\title{
THE GUARDIAN OF THE GATE.
}

\author{
By Rev. A. D. Belden, B.D. \\ Westcliff-on-Sea, England.
}

There is nothing that brings true mysticism into such disrepute as the insistence upon a mysterious interpretation in matters of religion where an obviously simple one is possible and apt. Religion of course must ever possess its mystery since God is infinite, but also the devout soul will always be growing in the knowledge of the infinite. It is indeed our bounden duty to be ever extending the frontier of understanding into the no-man's land of mystery.

A striking illustration of this undue mysticism in interpretation is provided by the treatment meted out to Christ's famous saying concerning the keys of the kingdom of heaven. "Thou art Peter, and upon this rock I will build my church . . . and I will give unto thee the keys of the kingdom of heaven and whatsoever thou shalt bind on earth shall be bound in heaven, and whatsoever thou shalt loose on earth shall be loosed in heaven".

Here Jesus is conferring upon someone a truly awful power, sublime in its possibilities of good, heart-shaking in the magnitude of its responsibility. In somebody's custody lie the keys of that kingdom of light and love and divine treasure, for which all humanity yearns. Some privileged person or persons guard the gateway to the Perfect Social Order, the reign of God on earth. Who is it?

\section{Saint oR Saints.}

Rome answers St. Peter, to whom these words were uttered, and his successors-those connected unbrokenly with him through the physical contact of the laying on of hands. We are all familiar with the idea-used often 
jocularly-of St. Peter as the warden of the gate of heaven. The objection to this is not so much that the power is thus conferred on certain men-the power in the present writer's view is for any who can successfully claim it-but that it should be viewed as given exclusively to these men. There are at least three overwhelming objections to such an interpretation.

1. It is contradicted by experience. It limits to a certain order of men the power of opening, not the church, but the Kingdom of God, to their fellows. But this power has been wielded by many outside the order recognized by Rome. Will anyone in these days deny that John Wesley, Charles Spurgeon, F. W. Robertson, D. L. Moody, had the power to bring men into the Kingdom of God?

2. It implies a unique sanctity in St. Peter whereas the context shows him falling speedily under the heary displeasure of Jesus. No one cares to deny that Peter became a great saint, but that he was the recipient of peculiar and exclusive grace at this point is not at all apparent. "Thou savourest not the things that be of God, but the things that be of men." "Before the cock crow thou shalt deny me thrice."

3. The parallel passage in St. John in which Jesus speaks of the power to bind and loose is addressed not to Peter, not even to the twelve apostles merely, but to the general company of disciples gathered in the upper room.

Protestantism has generally asserted that "the rock" to which Jesus refers is the confession of St. Peter, but unfortunately this looks too much like special pleading and it reflects Protestantism's general lack of imagination. What becomes of the play on the word "rock" if Peter is not primarily meant. It is Peter who is addressed, but not Peter as excluding others but as a type. This makes all the difference. It is Peter as an individual soul testifying to the overwhelming beauty and power of 
Christ, acclaiming His Saviourhood, witnessing to the Gospel, whom Christ hails as the rock-foundation of His Church and to whom He gives the power of the keys. But wherever that state of soul is found in Peter, or John, in Jones or Smith, in Joseph Parker or Bishop Crowther there, fashioned out of the rock of conviction is the Church of Christ and there using the mighty key of witness, is the power of turning men of God.

\section{The Kenper of the Keys.}

We see then clearly at last who it is that is called upon to bear this grave responsibility. It is none other than the true Church of Christ on earth, each several member coming into possession of this power according to the intensity of his or her conviction and the faithfulness of his or her witness. And is it not exhilarating to realize the sublime confidence in His true church which this statement reflects on the part of Jesus? Is it not thrilling to feel that the key-the key to that Kingdom Divine for which the hearts of all in their secret depths are yearning-is here to our hand? It is no uncommon experience for men to stand baffled, defeated before a closed door, because the key is not forthcoming. Suddenly there goes up a shout, "The key is here! the key is found"! Now we go in! we go in! According to our Lord there is no room for doubt but that the church will, ultimately, be faithful to her trust. He does not anticipate failure for ever on her part. Clear-eyed as He was concerning the faults and failings of $\mathrm{His}$ disciples $\mathrm{He}$ nevertheless asserts the invincibility of the church. "The gates of death, or hell, shall not prevail against it." In these days of a widespread consciousness of the church's failure it is well, to remind ourselves of this high faith of Christ's in the ultimate honour and triumph of His disciples.

Here then is the great simple meaning of this supposedly mysterious saying of our Lord's. It is the strong- 
est possible statement of the responsibility of every Christian disciple and of the church for such a witness to Christ as shall, by the conviction it brings to men, open to them the gateway of the Eternal Kingdom. The guardian of the gate is every true Christian soul, and all true Christian souls, whether Catherine Booth or Katie Lee, the Angel Adjutant, opening the way of life to hardened criminals in modern London, or St. Peter or St. Paul, opening the mystery of the forgiveness of sins to citizens of the Roman Empire.

\section{The Kers Themseldes.}

And these keys, what are they? Christ speaks as though there were a bunch of them-keys it may be of cuter and inner doors, or of lower and upper locks, for possibly the gates of the kingdom do not yield easy entrance.

Is it not difficult to see that at least there are three keys that need vigorous use to 'open the kingdom of heaven' to other souls?

\section{The Key of Conviction.}

There is the key of a great conviction. Only a convinced soul can convince others, only a convicted church can convict the world. Peter's blessedness consisted in the uprush within him of an overwhelming conviction as to the dignity and worth of Christ. Here was the One who must be obeyed, here was the King of the Kingdom! The Spirit of the Father working in his soul had illumined his understanding of Jesus and the great testimony leapt to his lips and would not be kept back-"Thou art the Christ, the Son of the Iiving God"'. Jesus was the highest he had ever seen or known and Peter chose the highest term he could find in which to express the overpowering sense of Christ's worth that had come to him. It is significant that St. John associates this power of the keys with the gift of the Holy Spirit whose work he de- 
fines peculiarly as that of conviction. The world is always wanting to know, very wistfully, how far the church is really convinced of its own beliefs and it is very weary and impatient of a mere 'hearsay' testimony. It listens for the ring of genuine conviction in our voices and it looks for the hall-mark of sincerity in our lives.

This key is only produced in the foundry of experience. It cannot be glibly assumed. The imitation key is not weighty enough to turn the lock. It was because Peter had been with Jesus that he knew his Lord's worth. His conviction was rooted like rock in the everlasting mountains of reality, unmovable, unshakable, capable of bearing any weight.

"Whoso hath felt the Spirit of the Highest

Cannot confound Him or deny,

Yea-O World-though thou deniest,

Stand thou on that side-for on this am I."

Wherever such profound conviction exists there is the power that moves the doubting souls of men to make fresh trial of faith. 'Do you really believe?' is the world's yearning cry to the church, and only a confident and evidently genuine 'Yea' will win a respectful hearing for the great message.

\section{The Key of Witness.}

It is a bunch of keys. Where one is the other will be. Let this conviction seize upon a soul and it cannot keep silence-the news is too good-it means too much for other souls, to be kept to oneself. And what a difference it makes to use this key of witness. Suppose this witness had never been heard in the British Isles as it has not yet been heard in certain districts of Central Africa. Just as the men whose sight has always been normal oannot understand the blind man's agony and loss, so we who have grown up in a land of light with an open Bible and a free witness fail lamentably to realize the loss that its 
absence means to a land and people. The condition of our evangelized country is like that of a vestibule to the $\mathrm{Ni}$ vine Kingdom, the door of which is ever and anon opened so that through it there comes streaming the light and beauty of the Kingdom inviting all to enter who will. But in lands where the gospel is little or ill-known there is no such opening door yielding illumination and providing a constant attraction and invitation.

It is very wonderful what the personal use of this key of witness can accomplish. One thinks for example of an obscure youth whose name is not known to history. He was an apprentice to a small shoemaker in Kettering. Being a Christian youth he saw no reason for remaining silent about it and in a shop, the moral atmosphere of which was decidedly bad, he raised the standard of Christian purity. How far he affected the shop is not known, but how far he affected the world is better appreciated. For a companion apprentice became interested through his influence in the Kingdom of God and passed through the gate that he had opened. The young man he influenced was William Carey, and with that noble pioneer of Missions there passed through that gate potentially a countless host of souls from all the nations upon earth. It is a thrilling privilege to be a guardian of the Gate.

When will the church rise to the full splendor of its power of witnessing for Christ? So many of its members are dead and silent. Just a key-word or two would introduce needy souls about them to the comfort and the glory of the Kingdom, but those words are not uttered, the witness is not borne. "Whosoever sins ye retain on earth, they shall be retained in heaven", there is expressed your awful responsibility and mine, if we are unfaithful in our witness. How many souls may still be fast-bound in the foul prisons of sin because you have never spoken a liberating word of testimony concerning the saving grace of God in Christ! Be not idle janitors 
of such a store-house of treasure as is the Kingdom of Heaven! Jesus warns us that upon the faithful witness of His disciples God has placed the full weight of human destiny, if they do not spread the light, darkness will still possess the people. There is an ancient legend that the Angels of heaven said to the Lord upon His ascension"Lord! What are the prospects of the Kingdom upon the earth"? And He replied, "I am trusting to Peter and his fellow disciples". "But, Lord", asked the angels, "suppose they fail you" "I have no other plan", said the Isord solemnly. "they will not fail". He has no other plan. For good or ill the salvation of men depends on the testimony of men. "Ye shall be my witnesses" is the Jjord's chosen method of bringing the world to God.

\section{The Key of Sacrifice.}

The third key that hangs on the bunch at the guardian's girdle is the key of suffering. The blood of the martyrs is the seed of the church-it is the 'open sesame' of the Kingdom of God-for it is the irrefragable seal set to their testimony. Men may champion an error or even a prejudice and a delusion in the stubborness of intellectual pride, but they will only suffer-as Christian martyrs have suffered-for what they feel to be real and true. Nothing has won a hearing for Christ with the world so surely as His Cross. It is a master key.

"He only could unlock the gate

Of heaven and let us in."

And when men see that key in our hand then they know we have the wardenship of the gate. It is often the crowning argument, the final appeal. When Paul looked upon the stoning of Stephen it was the beginning of the great change for him. For every martyr that Rome slew an inquirer sprang up to knock upon the sacred gate and to find entrance. The terrible Boxer rebellion in China some twenty years ago tore up Christian churches by the 
roots, but in doing so it scattered the sacred seed of testimony far and wide through China and by blood-marked doors souls crowded into the Kingdom of Christ.

"ILove's strength standeth in Love's sacrifice", and when men see what we can suffer and sacrifice for the Kingdom they begin to take it seriously at last.

Do you remember what Little Em'ly said in her memorable letter to David Copperfield, "When I see what you and uncle are, I can think what God is like and I can cry to Him". Their patient self-sacrifice had flung open the door of heaven to her.

\section{Open Sesame.}

In the providence of Almighty God every soul stands in a relationship of unique power to some other soul or souls, parent guardian, confidential friend, hero or heroine, to some circle of acquaintance. If this soul finds Christ those others will find Him. If this soul says 'Come' those others will come. Could any soul for one noment have even a partial vision of that Divine Kingdom, its infinite wealth, its manifold glories, its deathless art. its rapturous harmony, its ineffable peace, its infinitude of blessing, no soul could refuse the majestic privilege of opening the Kingdom of Heaven to new believers. Consecrated lips would burn to utter the magic words of grace, dedicated lives would mount with holy joy the altars of sacrifice, all would thrill with eager haste to fling open the gate of the new life to the perishing souls about them;

"That happy gate, which leads to where

Love is like sunshine in the air.

And love and law are both the same,

Named with an everlasting name." 